\title{
Resolusi Konflik Agama Dalam Integrasi Sosial Di Kabupaten Sidenreng Rappang
}

\author{
${ }^{1}$ Lukman Ismail, ${ }^{2}$ Kaharuddin, ${ }^{3}$ Nur Indah Fajrini $\mathbf{S}$ \\ ${ }^{1}$ Pendidikan Sosiologi, Universitas Muhammadiyah Makassar \\ Email : lukmanismail@unismuh.ac.id
}

\begin{abstract}
This study aims to describe the process of interfaith conflict resolution in social integration in the village of Bila Sidenreng Rappang, so that it can be used as a model for conflict resolution between religious communities in the archipelago. The type of method in this research is qualitative research, with a case study approach in which the informants consist of the village head, Muslim and Hindu community leaders, as well as the village community if they are alone. while the data collection technique is done by interviewing, observing, and documenting, then analyzing the data through data reduction, data presentation, and drawing conclusions. The results of this study indicate that the process of resolving religious conflicts in social integration in the village of Bila Sidenreng Rappang is about securing the implementation of minority worship, interaction between religious communities, the role of the government in creating social integration and harmony between religious communities.
\end{abstract}

Keywords : Resolution, Religious Conflict, Social Integration

\begin{abstract}
Abstrak
Penelitian ini bertujuan untuk mendeskripsikan proses resolusi konflik antar agama dalam integrasi sosial di Desa Bila Kabupaten Sidenreng Rappang, sehingga dapat dijadikan suatu model dalam penyelesaian konflik antar umat beragama di nusantara. Adapun jenis metode dalam penelitian ini yaitu penelitian kualitatif, dengan pendekatan Studi Kasus yang dimana Informannya terdiri dari kepala desa, tokoh masyarakat yang beragama islam dan hindu, serta masyarakat desa bila sendiri. sedangkan Teknik pengumpulan data dilakukan dengan cara wawancara, observasi, dan dokumentasi, kemudian analisis data melalui reduksi data, penyajian data, dan penarikan kesimpulan. Hasil penelitian ini menunjukkan bahwa, proses resolusi konflik agama dalam integrasi sosial pada Desa Bila Kabupaten Sidenreng Rappang adalah pengamanan peribadatan umat minoritas, interaksi antar umat beragama, peran pemerintah dalam situasi kondusif dan kerukunan antar umat beragama.
\end{abstract}

Kata Kunci : Resolusi, Konflik Agama, Integrasi Sosial 


\section{Aksiologi : Jurnal Pendidikan \\ dan Ilmu Sosial Volume : 1 No.2(2021) \\ E-ISSN : 2747-2752 / P-ISSN : 2774-5686}

\section{PENDAHULUAN}

Konflik antar agama merupakan konflik yang dapat ditimbulkan akibat dari perbedaan keyakinan, yang tidak bisa disiasati dengan sikap saling menghormati dan menghargai perbedaan. Di Indonesia kebebasan dalam menganut keyakinan atau kepercayaan telah diatur dalam UUD 1945 pasal 28E ayat 1 dan pasal 29 ayat 2 . Kebebasan dalam memeluk agama telah diatur secara jelas dan tidak ada satu pihakpun yang dapat ikut campur didalamnya. Undang undang juga mengatur kebebasan dalam beribadah dengan aman sesuai dengan keyakinan yang di anut. Sebagai negara nultikultural tentu saja di Indonesia tidak hanya terdiri dari 1 agama saja seperti juga contoh konflik antar ras. Pemerintah telah mengakui 6 agama sebagai agama resmi yang bisa dianut oleh para pemeluknya. Keenam agama tersebut antara lain islam, kristen, khatolik, hindu, budha dan konghucu.

Proses terjadinya suatu konflik dalam masyarakat yg berkaitang dengan agama biasanya terjadi karena faktor individu yang sangat tidak mendasar, seperti karena ketersinggungan agama. Selain itu, konflik cenderung terjadi biasanya disebabkan oleh perbedaan pendapat tentang budaya, suku, dan adatistiadat. Kelompok masyarakat tertentu menganggap dirinya paling benar dan tidak mau tersaingi oleh kelompok lain. Negara kita, Indonesia merupakan negara majemuk yang terdiri dari beragam budaya, adat istiadat, suku, dan agama. Peristiwa dari tanah air decade ini di mana perbedaan yang ada di masyarakat tidak mendukung terciptanya persatuan dan kesatuan bangsa. peristiwa yang sering terjadi adalah adanya konflik perbedaan agama dan keyakinan. Hal ini Menjadi perhatian banyak pihak, baik dari pemerintah sendiri dan kalangan masyarakat pada umumnya.
Pada dasarnya konflik terjadi bukan karena adanya perbedaan pandangan akan keyakinan yang diyakini. Namun, lebih kepada aksi individu atau kelompok yang menyulut kemarahan satu kelompok agama tertentu. Tentu saja hal ini harus segera diredam, karena jika tidak segera diatasi maka dampaknya tidak hanya merugikan bagi mereka yang beekonflik. Namun, juga bisa mengancam keutuhan dalan NKRI. Toleransi dan sikap salimg menghormati harus dijunjung tinggi sebagai upaya pengendalian timbulnya konflik

Upaya pencegahan konflik yang dilakukan dengan terstruktur, mendalam dan konsisten tentu akan membuat akar konflik mati dan potensi-potensi konflik tidak muncul kepermukaan. Sebagaimana tertuang dalam pasal 2 hingga pasal 7 Peraturan Pemerintah Nomor 2 Tahun 2015, upaya pencegahan konflik dapat dilakukan dengan berbagai cara, diantaranya membangun sistem peringatan dini konflik, penguatan kerukunan umat beragama, pendidikan bela Negara dan wawasan kebangsaan dan juga pemetaan wilayah konflik melalui penelitian yang komprehensif guna membabat habis akar konflik.

Pemerintah daerah juga dalam hal ini harus mulai merubah paradigma pencegahan konflik, bahwa upaya pencegahan konflik tidak dapat dilakukan dengan cara reaktif terhadap kasus konflik yang sedang terjadi dan cenderung "jalan sendiri". Pemerintah harus mampu merangkul berbagai kalangan, baik masyarakat, aparat kepolisian dan militer, organisasi sosial kemasyarakatan dan keagamaan guna mendapatkan masukanmasukan dalam setiap upaya pencegahan konflik karena merekalah yang pada umumnya berada pada ranah akar rumput (grassroot) dan memahami akar konflik. Pemerintah juga harus menyadarkan berbagai golongan tersebut bahwa semua golongan tersebut memiliki potensi yang sama besarnya untuk mengalami konflik 


\section{Aksiologi : Jurnal Pendidikan \\ dan Ilmu Sosial Volume : 1 No.2(2021) \\ E-ISSN : 2747-2752 / P-ISSN : 2774-5686}

agama. Namun demikian kenyataannya di kehidupan modern adaptasi sosial menjadi sulit diterapkan di tengah perbedaan prinsip masyarakat terlebih pada persoalan keyakinan atau agama. Ada yang sepakat dengan pengaruh modernisasi yang muncul namun, ada pula yang tidak bisa menerima karena pandangan dalam keyakinan dianutnya bertentangan dengan pengaruh modernisasi yang masuk dalam lingkungan masyarakat. Semakin gencarnya pengaruh modernisasi yang selalu berdatangan dan masuk dalam lingkungan masyarakat sehingga bisa dikatakan bahwa modernisasi juga merupakan faktor yang memicu munculnya perbedaan pandangan antara pemeluk agama dan perbedaan keyakinan.

Hal ini terjadi pada kelompok masyarakat di desa Bila Kecamatan Duapitue Kabupaten Sidenreng Rappang. Di desa tersebut terdapat kelompok masyarakat yang berbeda keyakinan yakni kelompok yang berkeyakinan Islam dan Hindu, menurut masyarakat yang tinggal di desa tersebut konflik yang terjadi biasanya adalah pemeluk agama tertentu kurang respek dengan pemeluk agama lain, biasa pula anak-anak mereka yang menjadi Sebab utama kurang baiknya hubungan antara pemeluk agama, anak pemeluk agama lain biasanya tidak saling bergaul karena perbedaan keyakinan, sesuai diperboleh diperbolehkan pemeluk lain. Biasa pula terjadi konflik antara anak remaja yang berbeda paham dengan pemeluk agama lain sehingga terjadi kesalah pahaman yang menimbulkan masalah-masalah antar pemeluk agama yang berbeda keyakinan.

\section{METODE}

Penelitian ini menggunakan metode penelitian yang besifat kualitatif deskriptif. Dengan menggunakan metode atau pendekatan studi kasus (case study). sedangkan Lokasi penelitian yang terkait dengan kasus yang peneliti akan teliti yakni di Desa Bila, Kecamatan Dua Pitue, Kabupaten Sidenreng Rappang.

Adapun Informan dalam penelitian ini terdiri dari kepala desa, tokoh masyarakat yang beragama islam dan hindu, serta masyarakat desa bila sendiri. sedangkan Teknik pengumpulan data dilakukan dengan cara wawancara, observasi, dan dokumentasi, kemudian analisis data melalui reduksi data, penyajian data, dan penarikan kesimpulan.

\section{HASIL DAN PEMBAHASAN}

Dalam hal ini tentunya ada beberapa upaya yang di lakukan dalam proses resolusi konflik agama dalam integrasi sosial pada Desa Bila Kabupaten Sidenreng Rappang adalah sebagai berikut

\section{a. Pengamanan Peribadatan Umat Minoritas}

Peribadatan itu sendiri merupakan suatu praktek ritual dalam menjaga hubungan antara manusia dengan Tuhannya, yang tentunya diperlukan rasa aman. salah satu bentuk upaya dalam menjamin pelaksanaan ritual atau peribadatan umat Hindu sebagai agama minoritas diperlukan pern berbagai stak holder seperti pemerintah, tokoh masyarakat dan pihak kepolisian sebagaimana yang terjadi pada Desa Bila Kabupaten Sidenreng Rappang sebagaimana wawancara dengan kepala Desa Bila H. Kuba (57 tahun) menyatakan bahwa:

"Kebijakan yang di lakukan pemerintah
untuk mendorong terciptanya dalam
proses resolusi konflik diantarannya
yaitu kami beserta para tokoh
masyarakat baik itu Hindu dan Islam,
sepakat untuk memberikan keleluasaan
masyaraakat yang beragama Hindu
untu menggunakan jalan dalam
perjalanan menuju tempat peribadatan
mereka selama dalam batas wajar, oleh
karena itu pemerintah bekerja sama
dengan aparat kepolisian agardiberikan 


\section{Aksiologi : Jurnal Pendidikan \\ dan Ilmu Sosial Volume : 1 No.2(2021) \\ E-ISSN : 2747-2752 / P-ISSN : 2774-5686}

pengawalan ketat" (Wawancara, Senin 21 September 2020).

Dari hasil wawancara tersebut, terkait dengan kebijakan pelaksanaan peribadatan umat Hindu telah mendorong terciptanya proses resolusi konflik sosial dalam integrasi sosial di Desa Bahwa pemerintah setempat bekerja sama dengan aparat kepolisian dalam membantu kelancaran peribadatan umat Hindu, maka dari itu integrasi dalam lingkungan masyarakat mulai tercipta secara perlahan hingga tidak ada lagi perbedaan dalam kehidupan bermasyarakat di desa tersebut.

\section{b. Interaksi Antar Umat Beragama}

Sebagai makhluk sosial, tentunya dibutuhkan suatu interaksi sosial secara berkelanjutan dalam suatu komunitas masyarakat dengan tanpa memandang perbedaan diantara keduanya. fenomena interaksi sosial tersebut dapat kita jumpai pada Desa Bila Kabupaten Sidenreng Rappang, yang dimana meskipun terdapat perbedaan keyakinan namun mereka tetap berinteraksi dengan tanpa memikirkan perbedaan latar belakang mereka masingmasing. Sebagaimana hasil wawancara oleh Hj. Pammi (55 tahun), menyatakan bahwa:

"Masyarakat saat ini sudah saling berbaur, sudah saling berinteraksi dengan mengesampingkan latar belakang agama dan lain-lain. Dan sejak terjadinya konflik agama pada beberapa tahun lalu, sampai pada saat ini sudah tidak pernah lagi terdengar adanya konflik dengan latar belakang agama, kalaupun ada itu penyebabnya hanyalah hal kecil dan tidak berlangsung lama" (Wawancara, Selasa, 22 dan Rabu, 23 September 2020).

Berdasarkan hasil dari pernyataan oleh informan tersebut, dapat disimpulkan bahwa proses resolusi konflik agama telah terjadi melalui interaksi dalam kehidupan sehari-hari meskipun dengan perbedaan latar belakang agama, dan keyakinan.

\section{c. Peran Pemerintah Dalam Situasi Kondusif}

Dalam menciptakan situasi dan kondisi yang kondusif antar umat beragama tidak terlepas dari peran pemerintah sebagaimana hasil wawancara dengan kepala desa Bila H. Kuba (57 tahun) menyatakan bahwa:

\begin{abstract}
"Peran pemerintah yaitu menciptakan suasana kehidupan beragama yang kondusif dalam masyarakat, dan juga berusaha meyakinkan warga masyarakat bahwa perbedaan keyakinan bukanlah sebuah penghalang dalam menciptakan integrasi sosial dalam kehidupan bermasyarakat" (Wawancara, Senin 21 September 2020).
\end{abstract}

Berdasarkan hasil wawancara tersebut, pemerintah memiliki peran sentral dalam meyakinkan warganya untuk mewujudkan integrasi sosial meskipun terdapat perbedaan keyakinan, dalam hal ini agama Hindu dan agama Islam di Desa Bila Kabupaten Sidenreng Rappang.

\section{d. Kerukunan Antar Umat Beragama}

Adapun inti dari proses resolusi konflik agama dalam integrasi sosial pada Desa Bila Kabupaten Sidenreng Rappang adalah terjadinya kerukunan antar umat beragama dalam hal ini pemeluk agama Hindu dengan pemeluk agama Islam sebagaimana hasil wawancara dengan kepala Dusun Muh Shaleh (53 tahun), menyatakan bahwa:

"Wujud kerukunan antar umat beragama yang terlihat saat sekarang ini yaitu, masyarakat sudah tergerak hatinya untuk melakukan gotong royong, besarnya toleransi terhadap hari-hari besar antar umat beragama, tidak ada lagi perbedaan besar dalam lingkup kehidupan 
beragama, dan batasan pergaulan antara anak-anak, remaja, dll, yang beda agama sudah tidak ada lagi, jadi sekarang anak-anak itu bergaul tidak pandang agama mi, tidak seperti dulu bahwa kalau anakyang agama hindu di larang bergaul sama anak yang beragama islam" (Wawancara, Senin 21, dan Rabu 23 September 2020).

Berdasarkan hasil wawancara tersebut dapat diketahui bahwa sudah banyak bukti dari wujud kerukunan antar umat beragama, diantaranya masyarakat mulai tergerak hatinya untuk melakukan gotong royong, besarnya toleransi terhadap hari-hari besar antar umat beragama, serta pergaulan dengan perbedaan latar belakang agama sudah tidak dibatasi. Jadi dulu anak-anak itu di larang untuk berinteraksi dengan yang beda agama, begitupun sebaliknya. Dan banyak lagi wujud kerukunan lainnya.

Selain itu, adapun faktor pendorong terwujudnya kerukunan antar umat beragama di Desa Bila Kabupaten Sidenreng Rappang, sebagaimana hasil wawancara dengan tokoh masyarakat La Wello (64 tahun) yang menyatakan bahwa:

"Ada beberapa faktor pendukung terwujudnya kerukunan antar umat beragama, diantaranya toleransi terhadap perbedaan agama, dan juga sudah ada kesadaran diri sebagai makhluk sosial, serta adanya tuntutan kebutuhan" (Wawancara, Senin 21, dan Rabu 23 September 2020).

Dari hasil wawancara tersebut, dapat kita ketahui bahwa faktor pendukung terwujudnya kerukunan antar umat beragama yaitu, Besarnya toleransi terhadap perbedaan keyakinan, adanya kesadaran diri sebagai makhluk sosial, serta tuntutan kebutuhan. Sehingga kerukunan antar umat beragama saat ini sudah sangat baik. Masyarakat sudah menyadari bahwa kerukunan antar umat beragamadalam kehidupan beragama ini sangatlah penting, yang secara tidak sadar membuat mereka akan saling berinteraksi, seperti misalnya pedagangdan pembeli, serta beberapa lagi contoh lainnya.

Berikut ini terdapat gambar terhadap alur dalam penelitian ini adalah sebagai berikut:

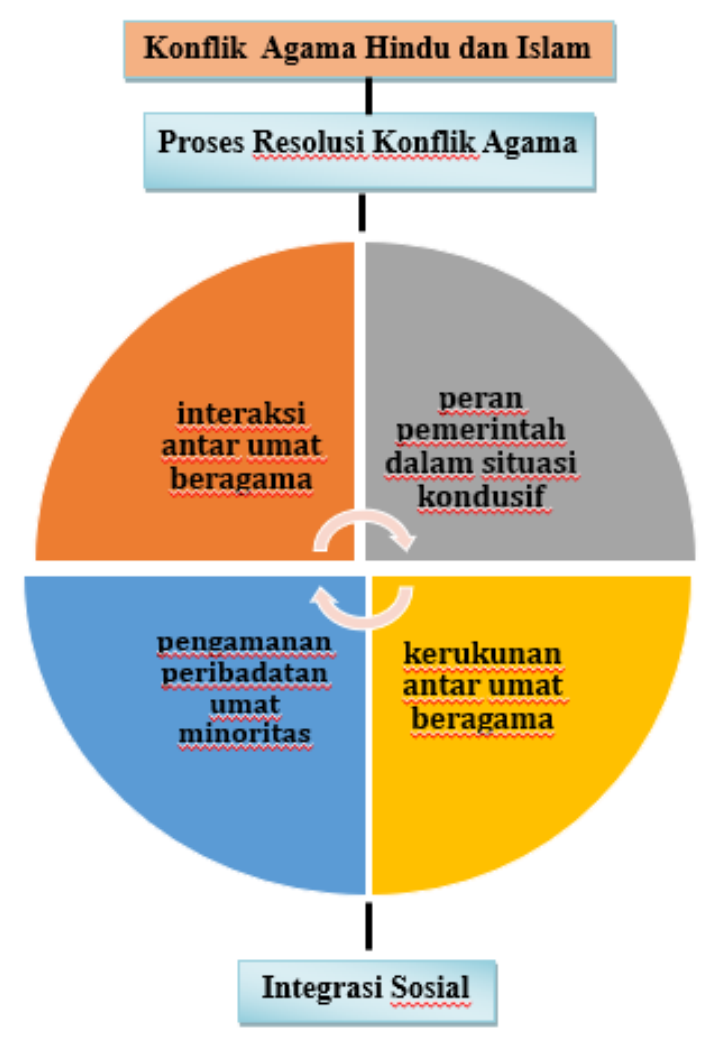

gambar 1

\section{KESIMPULAN}

Adapun kesimpulan dari proses resolusi konflik agama dalam Integrasi Sosial pada Desa Bila Kabupaten Sidenreng Rappang yang awalnya mengalami kesulitan, namun berkat peran atau usaha dari berbagai stake holder seperti pemerintah setempat, tokoh masyarakat serta warga masyarakat dari masingmasing umat agama Hindu dengan agama Islam sehingga integrasi sosial dalam kehidupan bermasyarakat dapat terwujud dengan baik, sehingga tercipta kerukunan antar umat beragama melalui pengamanan peribadatan umat minoritas, interaksi antar umat beragama, peran pemerintah 
dalam situasi kondusif, dan kerukunan antar umat beragama.

\section{DAFTAR PUSTAKA}

Anwar, Yesmil, dan Adang,. 2013. Sosiologi untuk Universitas. Bandung : Refika Aditama

Bakry Hendry. 2015. Resolusi Konflik Melalui Pendektan Kearifan Local Pola Gandong Di Kota Ambon. Jurnal. Tidak diterbitkan. Megister Ilmu Politi Universitas Hasanuddin.

Bornard Raho. 2007. Teori Sosiologi Modern. Jakarta : Prestasi Pustaka Publisher

Chandra, Robby. 1992. Konflik dalam kehidupan sehari-hari. Yogyakarta: Kanisius

Gulo. 2002. Metode Penelitian Sosial, Jakarta: Kencana Prenada.

Hoton, Paul, B., dan Chester L, 1991 Hunt, Sosiologi. 6 th Edition(terjemahan), Jakarta : Erlangga.

John W. Creswel. 2006 . Research Design Pendekatan Metode Kualitatif.

Kaharuddin., Hasan, Z. B., Akib, E., Dawi, F., \& Ernawati, A. (2013). Social Conflict On Arak (Ballo) Drinkers'in Gowa Regency, South Sulawesi Indonesia. South Sulawesi Indonesia Source: Indian Streams Research Journal [2230-7850] 3(3).

Maleong, Lexy J. 1989. Metodologi Penelitian Kualitatif. Bandung : PT Remaja Rosdakarya Offiset.

Musahadi (Ed.). 2007. Mediasi dan Resolusi Konflik di Indonesia. Semarang: WMC.Semarang

Nursalam, Suardi. (2016). Teori Sosiologi. Yogyakarta Writing Revilution.
Penerjemah Achmad F. S. Jakart. CV Rajawali.

Peter L. Berger and Thomas Luckman. 1990. Tafsir Sosial atas Kenyataan. Jakarta : LP3S,

Raharjo Wasisto. (2013). “Kearifan Lokal Sebagai Resolusi Konflik Keagamaan" Jurnal Sosial Kebudayaan.

Ritzer George, Goodman J. Douglas, (2010). Teori Sosiologi Modern.Jakarta : Kencana Pernada Media Group.

Robertson, R. 1988. Agama dalam Analisa dan Intrepetasi Sosiologis.

Saiffudin, A. F. 1986. Konflik dan Integrasi. Pubahan Faham dalam agama Islam. Jakarta CV Rajawali.

Soerjono, Soekanto. (2000) Sosiologi Suatu Pengantar.Jakarta : rajawali press.

Usman,S.1995. Integrasi dan Ketahanan Nasional. Sumbangan sosialterhadap ketahanan nasional. penyunting: Ichlasul Amal dan Armaidy

Wirawan. 2010. Konflik dan Manajemen Konflik: Teori, Aplikasi, dan Penelitian. Jakarta: Salemba Humanika.

Zuldin Muhammad. 2013. "Konflik Agama Dan Penyelesaiannya Kasus Ahmadiyah Di Kabupaten Tasikmalaya Jawa Barat" Jurnal. Tidak diterbitkan. Fakultas Ilmu Sosial Dan Politik UIN Sunan Gunung Djati 